\title{
Electrohydraulic lithotripsy for hepatolithiasis in a stenotic intrahepatic bile duct after Roux-en-Y hepaticojejunostomy
}

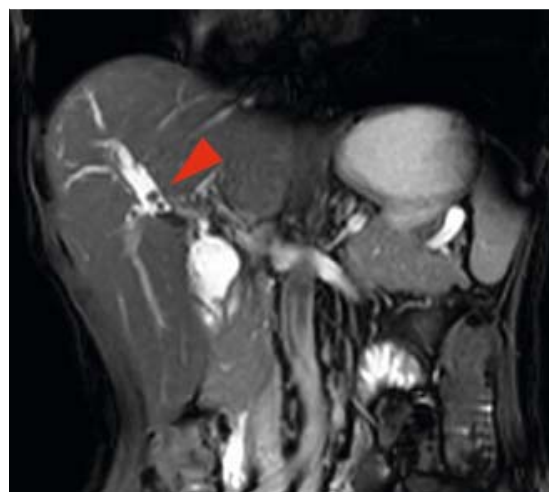

- Fig. 1 Magnetic resonance cholangiopancreatography revealed stones in the right hepatic bile duct (red arrowhead).

Digital single-operator cholangioscopy (DSOC) has increasingly been used in combination with electrohydraulic lithotripsy (EHL) to remove impacted stones, confluence stones, and stones in patients with surgically altered anatomy [1-4]. We present a case of hepatolithiasis in a stenotic intrahepatic bile duct after Roux-en-Y hepaticojejunostomy treated by EHL using DSOC (SpyGlass DS system; Boston Scientific Corp., United States) inserted through a colonoscope with a large working channel.

A 56-year-old woman with a history of Roux-en-Y hepaticojejunostomy for congenital biliary dilation and pancreaticobiliary maljunction was referred for treatment of hepatolithiasis. She underwent endoscopic retrograde cholangiography (ERCP) at the referring institution due to elevated hepatobiliary enzymes and hepatolithiasis noted on magnetic resonance cholangiopancreatography ( Fig.1). There, the endoscopist could not remove the stones but managed to insert a plastic biliary stent.

The patient was admitted to our hospital and ERCP was performed using a colonoscope with a 3.7-mm working channel (CF-HQ290ZI; Olympus Corp., Japan) ( $\triangleright$ Video 1). Fluoroscopy confirmed multiple stones in the right intrahepatic bile

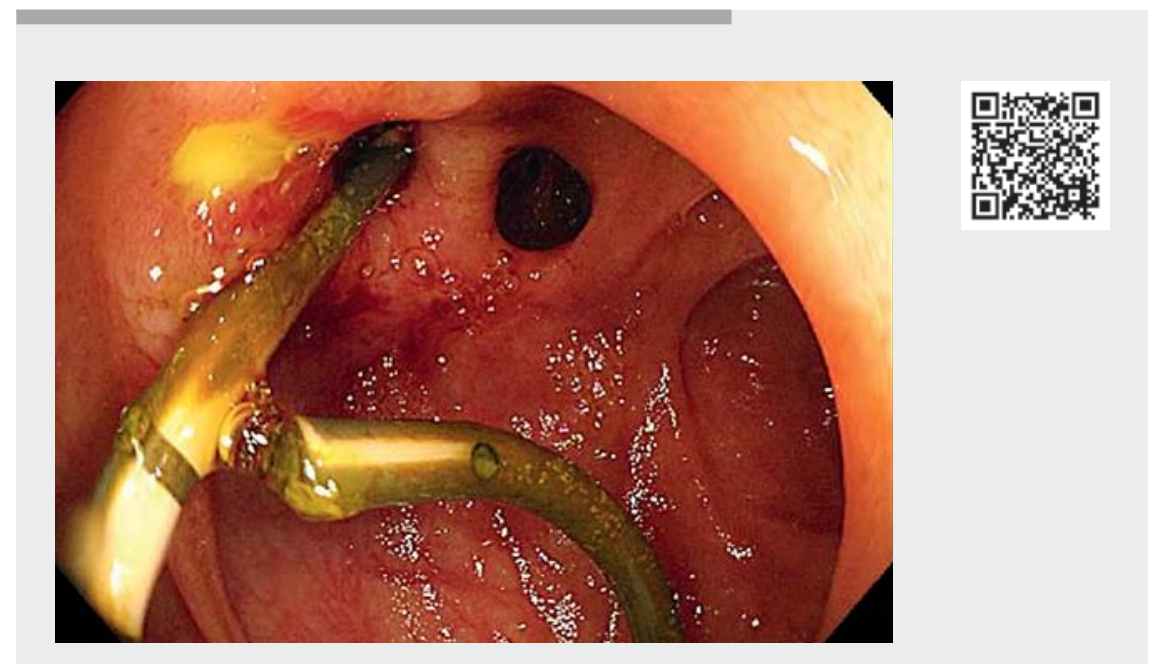

Video 1 Electrohydraulic lithotripsy for hepatolithiasis in a stenotic intrahepatic bile duct after Roux-en-Y hepaticojejunostomy.

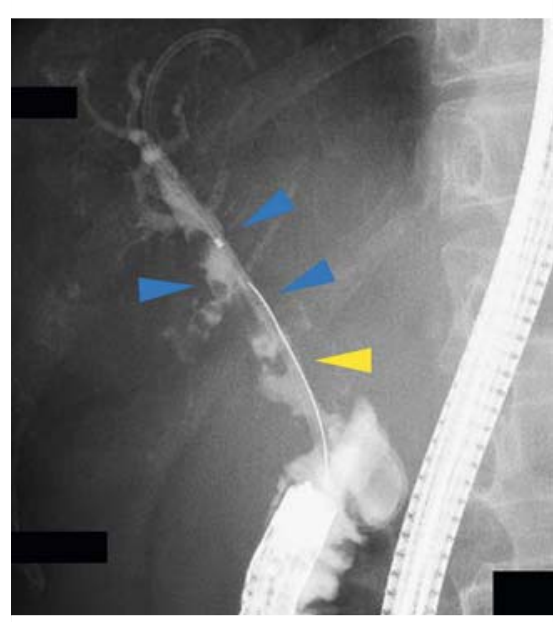

- Fig. 2 Intrahepatic biliary stenosis (yellow arrowhead) and multiple filling defects suggestive of hepatolithiasis (blue arrowheads) were observed on fluoroscopy.

duct ( $\triangleright$ Fig. 2 ). The stones could not be removed using a retrieval basket or balloon. We therefore inserted a cholangioscope through the channel of the colonoscope, which revealed intrahepatic biliary stenosis in addition to multiple stones (> Fig.3). We dilated the biliary stenosis

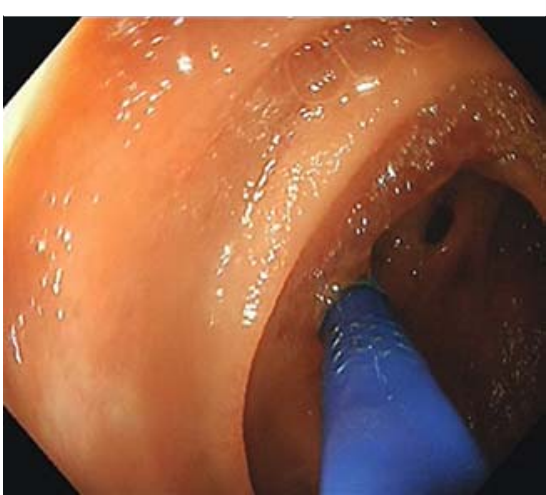

Fig. 3 Endoscopic view of the cholangioscope being inserted into the anastomosis of the right intrahepatic bile duct.

using a balloon dilator before reinserting the cholangioscope to perform EHL using Autolith (\$Fig.4). In two sessions all stones were removed ( $>$ Fig. 5). Brushing cytology of the biliary stenosis was negative for malignancy.

Successful EHL using DSOC through a colonoscope in a nonstenotic bile duct has been reported [5]. While percutaneous cholangioscopy and endosonographyguided lithotripsy are alternatives for dif- 


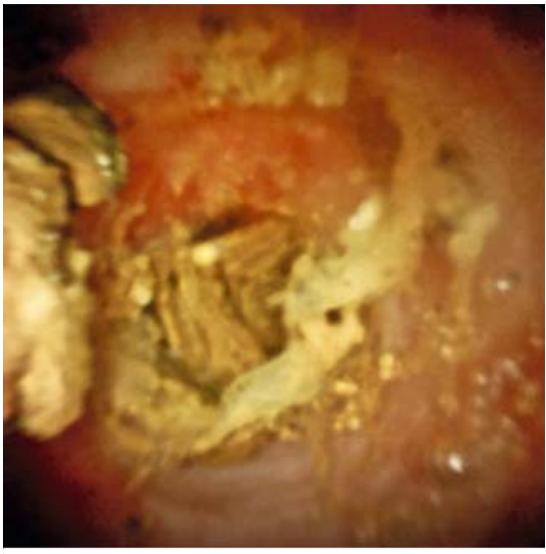

- Fig. 4 SpyGlass DS cholangioscopy showing the hepatolithiasis and intrahepatic biliary stenosis after dilation.

ficult stones in surgically altered anato$\mathrm{my}$, in those procedures the bile duct must be dilated and a new fistula created. Our method can be used in a stenotic and/or nondilated intrahepatic bile duct without creating a new fistula.

Endoscopy_UCTN_Code_TTT_1AR_2AK

\section{Competing interests}

The authors declare that they have no conflict of interest.

The authors

\section{Kenji Nakamura' ${ }^{\circledR}$, Takeshi Okamoto²,}

Tadashi Katayama', Yutaka Takigawa ${ }^{3}$, Katsuyuki Fukuda², Hiroshi Kishikawa ${ }^{1}$, Jiro Nishida ${ }^{1}$

1 Department of Gastroenterology, Tokyo Dental College, Ichikawa General Hospital, Chiba, Japan

2 Department of Gastroenterology, St. Luke's International Hospital, Tokyo, Japan

3 Department of Surgery, Tokyo Dental College, Ichikawa General Hospital, Chiba, Japan

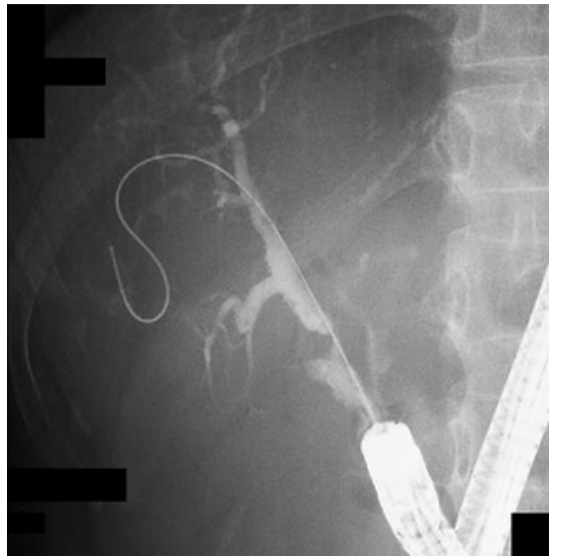

[5] Baron TH, Saleem A. Intraductal electrohydraulic lithotripsy by using SpyGlass cholangioscopy through a colonoscope in a patient with Roux-en-Y hepaticojejunostomy. Gastrointest Endosc 2010; 71: 650-651

Bibliography

Endoscopy 2022; 54: E61-E62

DOI 10.1055/a-1381-6152

ISSN 0013-726X

published online 5.3.2021

(c) 2021. Thieme. All rights reserved.

Georg Thieme Verlag KG, Rüdigerstraße 14,

70469 Stuttgart, Germany

- Fig. 5 Fluoroscopy confirmed the absence of residual stones in the right anterior duct.

Corresponding author

\section{Kenji Nakamura, MD, PhD}

Department of Gastroenterology, Tokyo Dental College, Ichikawa General Hospital, 5-11-13, Sugano, Ichikawa, 272-8513 Chiba, Japan

kenakamura@tdc.ac.jp

\section{References}

[1] Chen YK, Pleskow DK. SpyGlass single-operator peroral cholangioscopy system for the diagnosis and therapy of bile-duct disorders: a clinical feasibility study (with video). Gastrointest Endosc 2007; 65: 832-841

[2] Skinner M, Popa D, Neumann H et al. ERCP with the overtube-assisted enteroscopy technique: a systematic review. Endoscopy 2014; 46: 560-572

[3] Kawakami H, Kubota Y, Kawahata S et al. Peroral transhepatic cholangioscopy-guided electrohydraulic lithotripsy via an endoscopic ultrasonography-guided hepaticogastrostomy route for bile duct stones in a patient with Roux-en-Y anatomy. Endoscopy 2016; 48: E146-E147

[4] Weilert F, Binmoeller KF, Marson F et al. Endoscopic ultrasound-guided anterograde treatment of biliary stones following gastric bypass. Endoscopy 2011; 43: 1105-1108

\section{ENDOSCOPY E-VIDEOS \\ https://eref.thieme.de/e-videos}

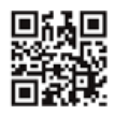

Endoscopy E-Videos is an open access online section, reporting on interesting cases and new techniques in gastroenterological endoscopy. All papers include a high quality video and all contributions are freely accessible online. Processing charges apply (currently EUR 375), discounts and wavers acc. to HINARI are available.

This section has its own submission website at https://mc.manuscriptcentral.com/e-videos 